\title{
Health care costs associated with hepatitis $C$ virus infection in First Nations populations in Ontario: a retrospective matched cohort study
}

\author{
Andrew Mendlowitz PhD MBiotech, Karen E. Bremner BSc, Jennifer D. Walker PhD, \\ William W.L. Wong PhD, Jordan J. Feld MD MPH, Beate Sander PhD, Lyndia Jones, \\ Wanrudee Isaranuwatchai PhD, Murray Krahn MD MSc
}

See related article at www.cmajopen.ca/lookup/doi/10.9778/cmajo.20200164

\section{Abstract}

Background: Colonization and marginalization have affected the risk for and experience of hepatitis C virus (HCV) infection for First Nations people in Canada. In partnership with the Ontario First Nations HIV/AIDS Education Circle, we estimated the publicly borne health care costs associated with HCV infection among Status First Nations people in Ontario.

\begin{abstract}
Methods: In this retrospective matched cohort study, we used linked health administrative databases to identify Status First Nations people in Ontario who tested positive for HCV antibodies or RNA between 2004 and 2014, and Status First Nations people who had no HCV testing records or only a negative test result (control group, matched 2:1 to case participants). We estimated total and net costs (difference between case and control participants) for 4 phases of care: prediagnosis (6 mo before HCV infection diagnosis), initial (after diagnosis), late (liver disease) and terminal (6 mo before death), until death or Dec. 31, 2017, whichever occurred first. We stratified costs by sex and residence within or outside of First Nations communities. All costs were measured in 2018 Canadian dollars.
\end{abstract}

Results: From 2004 to 2014, 2197 people were diagnosed with HCV infection. The mean net total costs per 30 days of HCV infection were $\$ 348$ (95\% confidence interval [Cl] \$277 to \$427) for the prediagnosis phase, $\$ 377$ (95\% Cl \$288 to $\$ 470)$ for the initial phase, $\$ 1768$ (95\% Cl \$1153 to \$2427) for the late phase and \$893 (95\% Cl - \$1114 to \$3149) for the terminal phase. After diagnosis of HCV infection, net costs varied considerably among those who resided within compared to outside of First Nations communities. Net costs were higher for females than for males except in the terminal phase.

Interpretation: The costs per 30 days of HCV infection among Status First Nations people in Ontario increased substantially with progression to advanced liver disease and finally to death. These estimates will allow for planning and evaluation of provincial and territorial population-specific hepatitis $\mathrm{C}$ control efforts.

bout 220 000-246 000 Canadians are infected with hepatitis $\mathrm{C}$ virus (HCV). ${ }^{1}$ Nearly half are unaware of their infection. ${ }^{1}$ Infection with $\mathrm{HCV}$ can lead to chronic hepatic inflammation, cirrhosis, hepatocellular carcinoma and death. ${ }^{2}$ In Ontario, $\mathrm{HCV}$ infection has a greater health burden than HIV infection. ${ }^{3}$

Hepatitis $\mathrm{C}$ virus infection places economic strain on the health care system, driven by expensive antiviral drugs and treatment of advanced liver disease. ${ }^{4,5}$ In 2013, the estimated cost of chronic HCV infection in Canada was \$161 million; this was expected to increase by $60 \%$ by $2032 .{ }^{6}$

Canada's sociopolitical history with First Nations people, one of the 3 major Indigenous populations, underlies the health disparities that continue to affect the population today. ${ }^{7}$ Among these disparities, higher incidence rates of $\mathrm{HCV}$ infection have been observed among certain First Nations popula- tions than among non-First Nations populations in Canada. ${ }^{8}$ In its commitment to the World Health Organization strategy for eliminating viral hepatitis by 2030, Canada has prioritized partnerships with First Nations populations. ${ }^{9}$ The objective of

Competing interests: William Wong and Murray Krahn report research support from the Canadian Liver Foundation. Jordan Feld reports institutional research support from AbbVie, Enanta Pharmaceuticals, Gilead Sciences and Janssen, and consulting fees from AbbVie and Gilead Sciences. No other competing interests were declared.

This article has been peer reviewed.

Correspondence to: Andrew Mendlowitz, andrew.mendlowitz@mail. utoronto.ca

CMAJ Open 2021 September 28. DOI:10.9778/cmajo.20200247 
this study was to estimate the health care costs and resource use associated with HCV infection, by phase of care, among Status First Nations populations in Ontario, stratified by sex and by residence within or outside of First Nations communities. An understanding of these measures is essential to planning and evaluating effective, culturally safe approaches to prevention and treatment of $\mathrm{HCV}$ infection.

\section{Methods}

\section{Partnership}

This study was conducted in partnership with the Ontario First Nations HIV/AIDS Education Circle and included First Nations community partners, ICES and academic researchers. Similar collaborations between First Nations organizations and researchers using ICES administrative data sets are described elsewhere. ${ }^{10-14}$ Access to the Indian Register was granted by the Chiefs of Ontario First Nations Data Governance Committee after the study was reviewed for compliance with the First Nations principles of ownership, control, access and possession (OCAP) and by Grand Council Treaty \#3. Permission to access data for members of communities in the Kenora Chiefs Advisory was not granted; thus, they were excluded from the analysis.

\section{Study design and population}

We conducted a retrospective matched cohort study to evaluate health care costs from the provincial public payer perspective. We identified First Nations people in Ontario registered under the Indian $A c t^{15}$ using the Indian Register. The Indian Register includes demographic and administrative information for all First Nations people who have successfully applied for Indian status under the Indian Act (i.e., "Status First Nations"). We obtained HCV testing records from Public Health Ontario.

We identified Status First Nations people who had tested positive for HCV antibodies or RNA between Jan. 1, 2004, and Dec. 31, 2014, at age 18-105 years, and followed them until death or Dec. 31, 2017, whichever occurred first. Participants were linked to administrative data sets held at ICES (Appendix 1, available at www.cmajopen.ca/content/9/3/ E897/suppl/DC1) by means of unique encoded identifiers and analyzed at ICES. People who had a valid Ontario Health Insurance Plan number at cohort entry and end of follow-up were included. People were excluded if they were potentially coinfected with HIV or hepatitis B virus, or if their HVC infection was presumed to be spontaneously cleared or acute resolved (Table 1$)$.

Control participants were Status First Nations people with no HCV testing record or only negative results of HCV testing. For the terminal phase of care $(6$ mo before death from any cause), control participants who died during the observation period were matched 2:1 at 6 months before death to case participants who had died. All remaining unmatched control participants were censored 6 months before death or on Dec. 31, 2017, whichever occurred first, and were randomly assigned pseudo diagnosis dates based on the month and year distribution of the case participants' $\mathrm{HCV}$ infection diagnosis

\begin{tabular}{|c|c|}
\hline \multicolumn{2}{|c|}{ Table 1: Exclusion criteria } \\
\hline $\begin{array}{l}\text { Exclusion } \\
\text { criterion }\end{array}$ & Definition \\
\hline $\begin{array}{l}\text { Spontaneous } \\
\text { clearance }\end{array}$ & $\begin{array}{l}\text { - Negative HCV RNA test result } 12 \text { mo after } \\
\text { positive HCV antibody test result and no } \\
\text { record of positive HCV RNA test result within } \\
12 \text { mo after first positive test result }\end{array}$ \\
\hline Acute resolved & $\begin{array}{l}\text { - Negative HCV RNA test result within } 12 \text { mo } \\
\text { after positive HCV RNA test result and no } \\
\text { record of HCV-related treatment between } \\
\text { testing dates (Appendix } 2 \text {, Supplemental } \\
\text { Table S3, available at www.cmajopen.ca/ } \\
\text { content/9/3/E897/suppl/DC1) } \\
\text { - The person never reverted to HCV RNA } \\
\text { positive }\end{array}$ \\
\hline HIV infection & $\begin{array}{l}\text { - Record in Ontario HIV database } \\
\text { - HIV diagnostic code in administrative data } \\
\text { (Appendix 2, Supplemental Table S1) }\end{array}$ \\
\hline HBV infection & $\begin{array}{l}\text { - Positive HBV test result in Public Health } \\
\text { Ontario testing records } \\
\text { - HBV diagnostic code in administrative data } \\
\text { (Appendix 2, Supplemental Table S1) }\end{array}$ \\
\hline
\end{tabular}

dates. Control participants with at least 6 months of observation time between their pseudo diagnosis date and censor date were matched 2:1 to case participants at the start of the prediagnosis phase (6 mo before $\mathrm{HCV}$ infection diagnosis date), initial phase (period following diagnosis with no liver disease) and late phase (liver disease). Each control participant was matched only once. Case and control participants for whom First Nations community residence was not known during the year of each match were excluded.

Control and case participants were greedy matched by hard-matching on sex and age within 2 years. They were then matched within a caliper width of 0.2 standardized difference of the logit of the propensity score based on Johns Hopkins ACG System, Aggregated Diagnosis Groups (ADGs) category $^{16}$ (excluding ADG 32 - Malignancy for late phase), and records of mental health or substance abuse conditions during the year before matching date, age at HCV infection diagnosis, community residence status and rurality. ${ }^{17} \mathrm{We}$ evaluated the quality of each match using descriptive statistics and the weighted standardized differences of matching variables between case and control participants. ${ }^{18}$

\section{Cohort characteristics}

We identified residence within or outside of a First Nations community at the year of phase entry using postal and residence codes from the Registered Persons Database, Discharge Abstract Database and National Ambulatory Care Reporting System. ${ }^{13}$ We used validated algorithms within the administrative data sets to detect complications related to liver disease, and HCV-specific drug prescription claims were captured (Appendix 2). ${ }^{19}$ We scored multimorbidity using ADGs.

Severe mental illnesses may be overrepresented in people at high risk for $\mathrm{HCV}$ infection. ${ }^{20}$ Depression, bipolar mood 
disorder, anxiety and stress-related disorders are prevalent and may be complicated by infection. ${ }^{21-23}$ We identified flags for mental health and substance abuse disorders using methods developed by ICES (Appendix 2), supplemented with Ontario Health Insurance Plan service codes. ${ }^{24}$ As alcohol use can have a compounded effect with $\mathrm{HCV}$ infection, further affecting deterioration of the liver, we identified alcohol use disorder separately using related diagnostic codes (Appendix 2). ${ }^{25}$

\section{Outcomes}

We used a phase-based approach to estimate costs over the natural history of disease. ${ }^{4,26-28}$ Patients who had a record of decompensated cirrhosis, hepatocellular carcinoma or liver transplantation (Appendix 2) were allocated to the late phase 3 months before the date of the first record. If that date was before their $\mathrm{HCV}$ infection diagnosis, they entered the late phase on their diagnosis date. The phase lengths were defined by means of joinpoint analyses and expert opinion from physicians with in-depth knowledge of HCV infection (J.J.F., M.K.) (Appendix 3, available at www.cmajopen.ca/content/9/ 3/E897/suppl/DC1).

We estimated provincial total and resource-specific costs for inpatient and ambulatory care, physician and diagnostic services, drugs for those aged 65 years or more, complex continuing care, home care and long-term care for case and control participants using standard person-level costing methods for administrative data (Table 2). ${ }^{29} \mathrm{We}$ adjusted costs to

Table 2: Resource categories included in the cost estimates

\begin{tabular}{|c|c|}
\hline $\begin{array}{l}\text { Resource } \\
\text { category }\end{array}$ & Included services* \\
\hline Outpatient visits & $\begin{array}{l}\text { Hospital outpatient clinic services, NACRS } \\
\text { visits to dialysis clinics, NACRS visits to } \\
\text { cancer clinics }\end{array}$ \\
\hline Physician services & $\begin{array}{l}\text { OHIP physician billings (including fee-for- } \\
\text { service and most of the shadow billingst) }\end{array}$ \\
\hline $\begin{array}{l}\text { Emergency } \\
\text { department visits }\end{array}$ & NACRS emergency department visits \\
\hline Same-day surgery & Same-day surgery procedures \\
\hline Inpatient care & $\begin{array}{l}\text { Inpatient hospital admissions and OMHRS } \\
\text { admissions to designated mental health } \\
\text { beds }\end{array}$ \\
\hline $\begin{array}{l}\text { Outpatient } \\
\text { prescription }\end{array}$ & Ontario Drug Benefit prescription claims \\
\hline $\begin{array}{l}\text { Laboratory tests/ } \\
\text { services }\end{array}$ & OHIP laboratory tests \\
\hline Other services & $\begin{array}{l}\text { OHIP nonphysician services, Assistive } \\
\text { Devices Program, rehabilitation services, } \\
\text { home care, complex continuing care and } \\
\text { long-term care }\end{array}$ \\
\hline \multicolumn{2}{|c|}{$\begin{array}{l}\text { Note: NACRS = National Ambulatory Care Reporting System, OHIP = Ontario } \\
\text { Health Insurance Plan, OMHRS = Ontario Mental Health Reporting System. } \\
\text { *Explanations of each administrative database can be found in Appendix } 1 . \\
\text { Additional details can be found in Appendix } 2 . \\
\text { tRefers to submitting a claim for services provided for which physicians are paid } \\
\text { a small percentage of the usual fee. }\end{array}$} \\
\hline
\end{tabular}

2018 Canadian dollars using health-sector-specific consumer price indices ${ }^{29,30}$ and standardized them to per 30 days within each phase by dividing each patient-level cost by each person's time in phase.

\section{Statistical analysis}

We used clustered analyses by matched set using generalized estimating equations ( $\gamma$ family and $\log$ link) to estimate net costs (difference between case and control participants) with each cost category as the dependent variable and HCV infection status as the independent variable. ${ }^{31}$ We used clustered bootstrap sampling, where matched sets were resampled, with 1000 replications and the percentile method to estimate $95 \%$ confidence intervals (CIs). Results were stratified by sex and by case participant residence within or outside of a First Nations community at matching date. All analyses were done with $\mathrm{R}$ version 3.6.3 (R Foundation for Statistical Computing), SAS version 9.2 (SAS Institute) and Stata version 15.1 (StataCorp).

\section{Ethics approval}

This study was approved by the University of Toronto Health Sciences Research Ethics Board.

\section{Results}

From 2004 to 2014, 2197 First Nations people were diagnosed with HCV infection (Figure 1). Most (1848 [84.1\%]) contributed time to a single phase after diagnosis (Appendix 4, available at www.cmajopen.ca/content/9/3/E897/suppl/DC1). After matching, 2096, 2077, 130 and 297 people with HCV infection contributed observation time to the prediagnosis, initial, late and terminal phases, respectively (Appendix 4).

The sociodemographic characteristics, mental health conditions and comorbidity data of the case and control participants in each phase at matching dates are presented in Table 3. For the prediagnosis and initial phases, the weighted standardized differences were 0.1 or less for all matching variables. Despite efforts to improve matching, case and control participants were less well matched on some ADGs for the late and terminal phases (Appendix 5, Supplemental Table S7, available at www.cmajopen.ca/content/9/3/E897/ suppl/DC1), likely owing to the small number of people with these conditions.

People with HCV infection spent, on average, 179, 2714, 1281 and 168 days in the prediagnosis, initial, late and terminal phases, respectively. They were older in the late and terminal phases (about $50 \mathrm{yr}$ ) than in the initial and prediagnosis phases (about $37 \mathrm{yr}$ ). In all phases, the majority were male and lived outside of First Nations communities. Substance abuse and addiction disorders were the most common comorbid conditions.

During the initial and late phases, 195 case participants (9.4\%) and 23 case participants $(17.7 \%)$, respectively, had records of an $\mathrm{HCV}$-related prescription, and $155(7.5 \%)$ and $21(16.2 \%)$, respectively, received direct-acting antiviral treatment. 


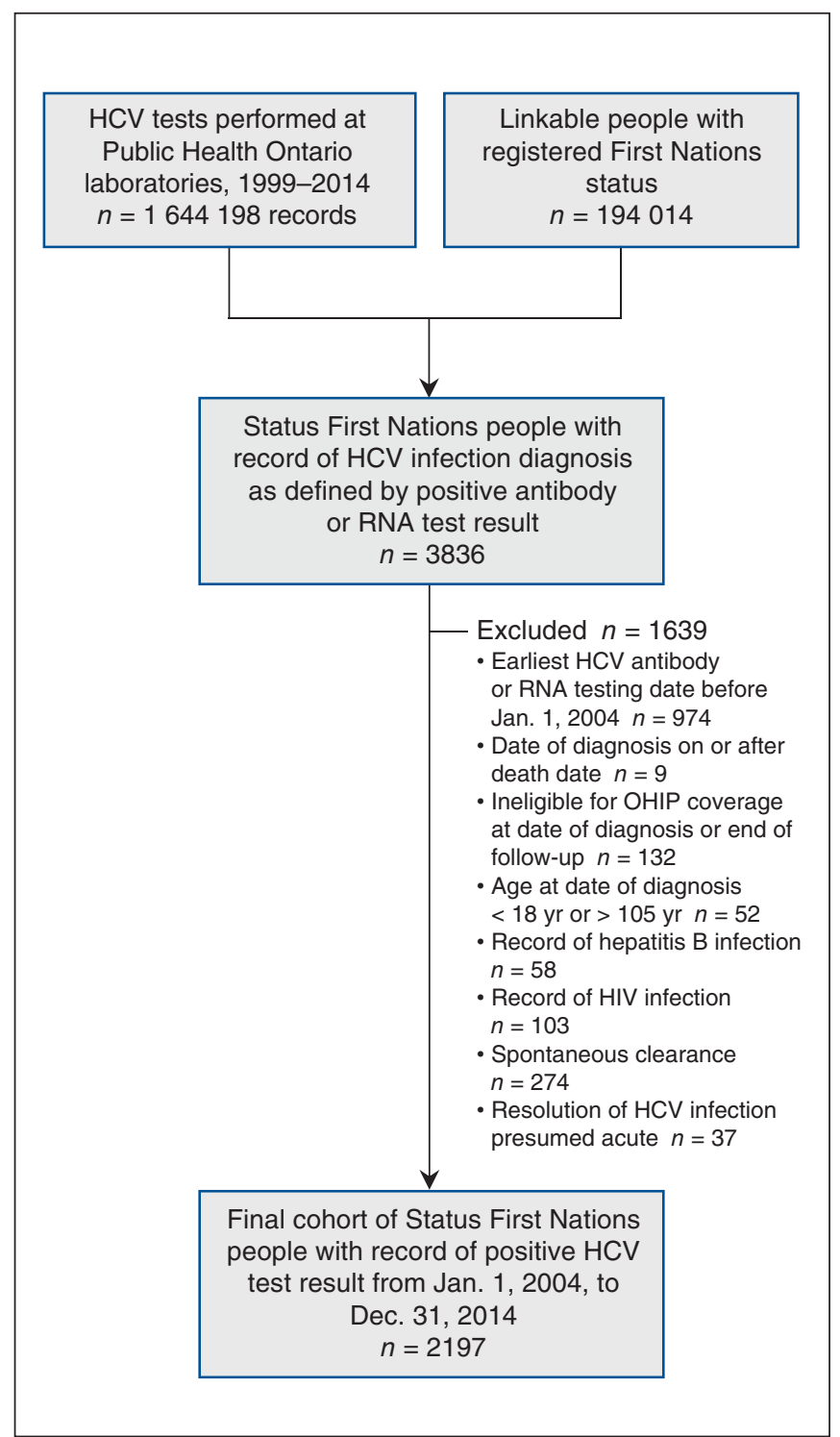

Figure 1: Flow diagram showing case selection. Note: HCV = hepatitis $\mathrm{C}$ virus, OHIP = Ontario Health Insurance Plan.

\section{Total costs}

Table 4 summarizes the mean total health care costs per 30 days by phase of care for the case and control participants. Among case participants, total costs were lowest in the prediagnosis phase (\$637), increased after HCV diagnosis (\$875) and increased substantially during the late phase (\$2786). Total costs were highest in the terminal phase for both case (\$8896) and control (\$8050) participants.

Outpatient prescriptions, physician services and inpatient care accounted for the highest proportions of costs (Table 4). Inpatient care accounted for $30 \%-50 \%$ of the health care costs in the prediagnosis, initial and late care phases, and $60 \%-70 \%$ of total costs in the terminal phase. For the prediagnosis, initial and late phases, costs were higher among case participants than control participants for nearly all resource categories. In the terminal phase, control partici- pants had higher costs for outpatient services (\$738 v. \$667), same-day surgery (\$31 v. \$17) and emergency department visits (\$271 v. \$249).

Other cost outcomes are described in Appendix 5, Supplemental Tables S8 to S11, and below.

\section{Net costs}

The mean net cost per 30 days increased from $\$ 348$ (95\% CI $\$ 277$ to $\$ 427)$ in the prediagnosis phase to $\$ 893$ (95\% CI $-\$ 1114$ to $\$ 3149$ ) in the terminal phase (Table 5).

Figure 2 summarizes the net costs per 30 days for case participants who resided within and outside of First Nations communities in the year of matching date. Total net costs were higher in the initial, late and terminal phases for those who resided outside of versus within First Nations communities. Negative net costs indicate that the costs were higher for the control participants than for the case participants. In the terminal phase, the mean net total costs per 30 days were -\$1844 (95\% CI $-\$ 5182$ to $\$ 1419)$ and $\$ 1289$ (95\% CI - \$892 to $\$ 3515)$ for those who resided within and outside of First Nations communities, respectively.

Net total costs per 30 days were higher for females than males in the prediagnosis, initial and late phases (Figure 3). In particular, females had consistently higher net costs for physician services, inpatient care and outpatient prescription drugs. In the terminal phase, net costs were higher for males than for females (\$1745 [95\% CI $-\$ 639$ to $\$ 4460]$ v. $-\$ 498$ [95\% CI $-\$ 3563$ to $\$ 2832])$.

\section{Interpretation}

Using administrative data to estimate the phase-specific provincial health care costs attributable to $\mathrm{HCV}$ infection among Status First Nations people in Ontario, we found that costs per 30 days increased with disease progression. Inpatient services, outpatient prescription drugs and physician services were the most costly resources. Female participants had higher net costs than male participants in the prediagnosis, initial and late phases of care, but males had higher net costs in the terminal phase. Net costs were consistently higher among those who resided outside of versus within First Nations communities, with the largest difference in the terminal phase. However, the large CIs around the net cost estimates indicate wide variations, and, therefore, definitive conclusions should be made with caution.

In our study, the average annual cost for Status First Nations people with HCV infection, before late-stage liver disease, was $\$ 10500,1.5$ times the average Canadian health care cost of $\$ 6867$ in $2018 .^{32}$ Our annual net costs were considerably higher than those estimated in 2005 in British Columbia, $\$ 1850$ (\$2230 in 2018 Canadian dollars ${ }^{30}$ ) for early infection and $\$ 6000$ (\$7234 in 2018 Canadian dollars ${ }^{30}$ ) for infection with advanced liver disease. ${ }^{4}$ Our mean annual late-phase net cost of $\$ 21216$ is similar to the cost of liver cancer care in the Ontario population (about $\$ 20000){ }^{27}$ These estimates would be considerably higher if a broader societal perspective including patient-borne and productivity costs were considered. ${ }^{33}$ 


\begin{tabular}{|c|c|c|c|c|c|c|c|c|}
\hline \multirow[b]{3}{*}{ Characteristic } & \multicolumn{8}{|c|}{ Cohort; no. (\%) of people* } \\
\hline & \multicolumn{2}{|c|}{ Prediagnosis phase } & \multicolumn{2}{|c|}{ Initial phase } & \multicolumn{2}{|c|}{ Late phase } & \multicolumn{2}{|c|}{ Terminal phase } \\
\hline & $\begin{array}{c}\text { Case } \\
n=2096\end{array}$ & $\begin{array}{c}\text { Control } \\
n=3916\end{array}$ & $\begin{array}{c}\text { Case } \\
n=2077\end{array}$ & $\begin{array}{c}\text { Control } \\
n=3875\end{array}$ & $\begin{array}{c}\text { Case } \\
n=130\end{array}$ & $\begin{array}{l}\text { Control } \\
n=249\end{array}$ & $\begin{array}{c}\text { Case } \\
n=297\end{array}$ & $\begin{array}{l}\text { Control } \\
n=545\end{array}$ \\
\hline $\begin{array}{l}\text { Length of phase, } \\
\text { mean } \pm S D, d\end{array}$ & $179 \pm 0$ & $179 \pm 0$ & $2714.5 \pm 1248.5$ & $2098.2 \pm 966.0$ & $1280.9 \pm 1086.1$ & $1092.2 \pm 826.5$ & $168.5 \pm 40.2$ & $168.3 \pm 40.7$ \\
\hline \multicolumn{9}{|c|}{ Demographic characteristics } \\
\hline \multicolumn{9}{|l|}{ Age, yr } \\
\hline Mean \pm SD & $36.7 \pm 11.4$ & $36.9 \pm 11.5$ & $36.7 \pm 11.1$ & $36.8 \pm 11.2$ & $50.1 \pm 9.4$ & $50.1 \pm 9.3$ & $48.8 \pm 12.3$ & $49.5 \pm 12.2$ \\
\hline Median (IQR) & $36(27-45)$ & $36(27-46)$ & $36(28-45)$ & $36(28-45)$ & $50(46-57)$ & $51(45-57)$ & $50(40-57)$ & $51(41-58)$ \\
\hline \multicolumn{9}{|l|}{ Age group, yr } \\
\hline$\leq 29$ & $665(31.7)$ & $1227(31.3)$ & $645(31.1)$ & $1221(31.5)$ & $6(4.6)$ & $10(4.0)$ & $25(8.4)$ & $35(6.4)$ \\
\hline 30-39 & $579(27.6)$ & $1080(27.6)$ & $594(28.6)$ & $1087(28.1)$ & $9(6.9)$ & $19(7.6)$ & $49(16.5)$ & $78(14.3)$ \\
\hline $40-49$ & $545(26.0)$ & $1018(26.0)$ & $550(26.5)$ & $1005(25.9)$ & 45 (34.6) & $82(32.9)$ & $68(22.9)$ & $134(24.6)$ \\
\hline$\geq 50$ & $307(14.6)$ & $591(15.1)$ & $288(13.9)$ & $562(14.5)$ & $70(53.8)$ & $138(55.4)$ & $155(52.2)$ & $298(54.7)$ \\
\hline \multicolumn{9}{|l|}{ Rural mail delivery area } \\
\hline No & $2088(99.6)$ & 3897 (99.5) & $2070(99.7)$ & $3863(99.7)$ & $130(100.0)$ & $249(100.0)$ & $--^{\star \star}$ & $539(98.9)$ \\
\hline Yes & $8(0.4)$ & $19(0.5)$ & $7(0.3)$ & $12(0.3)$ & $0(0.0)$ & $0(0.0)$ & $--^{* *}$ & $6(1.1)$ \\
\hline \multicolumn{9}{|l|}{ Sex } \\
\hline Female & $944(45.0)$ & $1728(44.1)$ & $945(45.5)$ & $1762(45.5)$ & $42(32.3)$ & $80(32.1)$ & $116(39.1)$ & $205(37.6)$ \\
\hline Male & $1152(55.0)$ & $2188(55.9)$ & $1132(54.5)$ & $2113(54.5)$ & $88(67.7)$ & $169(67.9)$ & $181(60.9)$ & $340(62.4)$ \\
\hline \multicolumn{9}{|c|}{ First Nations community status } \\
\hline $\begin{array}{l}\text { Outside of } \\
\text { community† }\end{array}$ & $1714(81.8)$ & $3142(80.2)$ & $1695(81.6)$ & $3075(79.4)$ & $112(86.2)$ & $216(86.7)$ & $259(87.2)$ & $477(87.5)$ \\
\hline Within community & $382(18.2)$ & $774(19.8)$ & $382(18.4)$ & $800(20.6)$ & $18(13.8)$ & $33(13.3)$ & $38(12.8)$ & $68(12.5)$ \\
\hline \multicolumn{9}{|c|}{ Mental health conditions $\ddagger$} \\
\hline Alcohol use disorder & $241(11.5)$ & $377(9.6)$ & $318(15.3)$ & $511(13.2)$ & $28(21.5)$ & $47(18.9)$ & $62(20.9)$ & $117(21.5)$ \\
\hline $\begin{array}{l}\text { Substance-related/ } \\
\text { addictive disorders§ }\end{array}$ & $657(31.3)$ & $1136(29.0)$ & $997(48.0)$ & $1787(46.1)$ & $43(33.1)$ & 82 (32.9) & $113(38.0)$ & $197(36.1)$ \\
\hline Depression & $61(2.9)$ & $101(2.6)$ & $96(4.6)$ & $175(4.5)$ & $--^{\star *}$ & $9(3.6)$ & $11(3.7)$ & $19(3.5)$ \\
\hline Anxiety & $165(7.9)$ & 284 (7.3) & $187(9.0)$ & 320 (8.3) & $-{ }^{* *}$ & $7(2.8)$ & $22(7.4)$ & $44(8.1)$ \\
\hline Bipolar & $10(0.5)$ & $16(0.4)$ & $13(0.6)$ & $23(0.6)$ & $-{ }^{\star \star}$ & $--^{\star \star}$ & $-{ }^{\star \star}$ & $-{ }^{\star \star}$ \\
\hline $\begin{array}{l}\text { Schizophrenia } \\
\text { spectrum disorder }\end{array}$ & $35(1.7)$ & $46(1.2)$ & $45(2.2)$ & $89(2.3)$ & $--^{* *}$ & $--^{* *}$ & $7(2.4)$ & $7(1.3)$ \\
\hline $\begin{array}{l}\text { Trauma-/stressor- } \\
\text { related disorders }\end{array}$ & $38(1.8)$ & $60(1.5)$ & $49(2.4)$ & $94(2.4)$ & $-{ }^{\star *}$ & $-^{\star \star}$ & $6(2.0)$ & $8(1.5)$ \\
\hline \multicolumn{9}{|l|}{ Comorbidity } \\
\hline $\begin{array}{l}\text { ADGs total score, } \\
\text { mean } \pm S D\end{array}$ & $4.3 \pm 3.6$ & $3.9 \pm 3.4$ & $5.3 \pm 3.7$ & $5.0 \pm 3.6$ & $6.7 \pm 4.4$ & $6.5 \pm 4.1$ & $7.5 \pm 4.8$ & $7.6 \pm 4.7$ \\
\hline $\begin{array}{l}\text { ADGs total score, } \\
\text { median (IQR) }\end{array}$ & $4(1-7)$ & $3(1-6)$ & $5(2-8)$ & $4(2-7)$ & $7(3-10)$ & $6(3-9)$ & $7(4-11)$ & $7(4-11)$ \\
\hline \multicolumn{9}{|l|}{$\begin{array}{l}\text { No. of ADGs } \\
\text { categories }\end{array}$} \\
\hline$\leq 3$ & 668 (31.9) & 1375 (35.1) & $628(30.2)$ & 1284 (33.1) & $-{ }^{\star \star}$ & $54(21.7)$ & $62(20.9)$ & 95 (17.4) \\
\hline $4-7$ & 702 (33.5) & $1280(32.7)$ & $762(36.7)$ & 1440 (37.2) & 41 (31.5) & $97(39.0)$ & $85(28.6)$ & $164(30.1)$ \\
\hline $8-10$ & $251(12.0)$ & $392(10.0)$ & $350(16.9)$ & $578(14.9)$ & $23(17.7)$ & $40(16.1)$ & $52(17.5)$ & $97(17.8)$ \\
\hline$\geq 11$ & $132(6.3)$ & $193(4.9)$ & $203(9.8)$ & $310(8.0)$ & 29 (22.3) & 47 (18.9) & 87 (29.3) & 163 (29.9) \\
\hline Nonuser/missing & $343(16.4)$ & $676(17.3)$ & $134(6.5)$ & $263(6.8)$ & $--^{* *}$ & $11(4.4)$ & $11(3.7)$ & $26(4.8)$ \\
\hline \multicolumn{9}{|c|}{$\begin{array}{l}\text { Note: } A D G s=\text { Aggregated Diagnosis Groups, } \mathrm{HCV}=\text { hepatitis } \mathrm{C} \text { virus, IQR = interquartile range, SD = standard deviation. } \\
\text { "Except where noted otherwise. } \\
\text { †Also included people who had an out-of-province residence code for the year of matching date. } \\
\text { †During the year before matching date. } \\
\text { §Also contains records pertaining to alcohol use disorder. } \\
\text { १The frequencies associated with each specific ADGs category can be found in Appendix 5, Supplemental Table S7. } \\
{ }^{\star *} \text { Suppressed to remove risk of reidentification as per ICES privacy rules. }\end{array}$} \\
\hline
\end{tabular}




\begin{tabular}{|c|c|c|c|c|c|c|c|c|}
\hline \multirow[b]{3}{*}{ Resource category } & \multicolumn{8}{|c|}{ Cohort; mean cost per $30 \mathrm{~d}, \$^{*}$ (\% of total) } \\
\hline & \multicolumn{2}{|c|}{ Prediagnosis phase } & \multicolumn{2}{|c|}{ Initial phase } & \multicolumn{2}{|c|}{ Late phase } & \multicolumn{2}{|c|}{ Terminal phase } \\
\hline & Case & Control & Case & Control & Case & Control & Case & Control \\
\hline Outpatient visits & $62(9.7)$ & $31(10.8)$ & $89(10.2)$ & $70(14.1)$ & $227(8.1)$ & $240(23.7)$ & $667(7.5)$ & $738(9.2)$ \\
\hline Physician services & $130(20.3)$ & $76(26.5)$ & $168(19.2)$ & $110(22.1)$ & $405(14.5)$ & $151(14.8)$ & $1056(11.9)$ & $875(10.9)$ \\
\hline $\begin{array}{l}\text { Emergency } \\
\text { department visits }\end{array}$ & $77(12.0)$ & $27(9.3)$ & $55(6.3)$ & $40(8.0)$ & $173(6.2)$ & $57(5.6)$ & $249(2.8)$ & $271(3.4)$ \\
\hline Same-day surgery & $8(1.3)$ & $9(3.1)$ & $9(1.0)$ & $10(2.0)$ & $33(1.2)$ & $16(1.6)$ & $17(0.2)$ & $31(0.4)$ \\
\hline Inpatient care & 252 (39.6) & $103(35.5)$ & 325 (37.2) & $172(34.7)$ & 1307 (46.9) & $332(32.7)$ & $5929(66.6)$ & 5261 (65.3) \\
\hline $\begin{array}{l}\text { Outpatient } \\
\text { prescription }\end{array}$ & $33(5.2)$ & $18(6.3)$ & $150(17.1)$ & $47(9.5)$ & 405 (14.5) & $105(10.4)$ & $215(2.4)$ & $201(2.5)$ \\
\hline $\begin{array}{l}\text { Laboratory tests/ } \\
\text { services }\end{array}$ & $28(4.4)$ & $11(3.7)$ & $17(1.9)$ & $9(1.9)$ & $21(0.8)$ & $10(1.0)$ & $17(0.2)$ & $12(0.1)$ \\
\hline Other services $†$ & $48(7.5)$ & $14(4.9)$ & $62(7.1)$ & $39(7.8)$ & $214(7.7)$ & $104(10.3)$ & 747 (8.4) & $662(8.2)$ \\
\hline Total & 637 (100.0) & $289(100.0)$ & 875 (100.0) & $497(100.0)$ & 2786 (100.0) & $1016(100.0)$ & 8896 (100.0) & 8050 (100.0) \\
\hline
\end{tabular}

\begin{tabular}{|c|c|c|c|c|}
\hline \multirow[b]{2}{*}{ Resource category } & \multicolumn{4}{|c|}{ Phase of care; mean net cost $(95 \% \mathrm{Cl})$ per 30 days, $\$^{*}$} \\
\hline & $\begin{array}{l}\text { Prediagnosis } \\
\text { phase }\end{array}$ & Initial phase & Late & Terminal \\
\hline Outpatient visits & $31(12$ to 54$)$ & $19(-9$ to 47$)$ & $-14(-190$ to 166$)$ & $-66(-312$ to 193$)$ \\
\hline Physician services & 53 (41 to 65$)$ & 58 (47 to 69$)$ & 255 (181 to 338$)$ & $182(-34$ to 448$)$ \\
\hline $\begin{array}{l}\text { Emergency } \\
\text { department visits }\end{array}$ & 50 (43 to 56$)$ & 15 (10 to 20$)$ & $116(66$ to 170$)$ & $-22(-77$ to 30$)$ \\
\hline Same-day surgery & $-1(-4$ to 3$)$ & $-1(-2$ to 0$)$ & 17 (3 to 34$)$ & $-14(-31$ to 1$)$ \\
\hline Inpatient care & 150 (106 to 202) & 153 (97 to 219$)$ & 975 (621 to 1378$)$ & $696(-975$ to 2487$)$ \\
\hline $\begin{array}{l}\text { Outpatient } \\
\text { prescription }\end{array}$ & 15 (9 to 20$)$ & $102(89$ to 115$)$ & 300 (171 to 443$)$ & $14(-73$ to 120$)$ \\
\hline $\begin{array}{l}\text { Laboratory tests/ } \\
\text { services }\end{array}$ & 17 (14 to 20$)$ & $8(6$ to 9$)$ & $11(4$ to 21$)$ & $5(0$ to 10$)$ \\
\hline Other services & 34 (7 to 65$)$ & $23(-4$ to 54$)$ & 109 (10 to 205$)$ & 85 (-198 to 389$)$ \\
\hline Total & 348 (277 to 427 ) & 377 (288 to 470) & 1768 (1153 to 2427 ) & $893(-1114$ to 3149$)$ \\
\hline
\end{tabular}

The mean end-of-life costs for case and control participants in our study were higher than costs in the last year of life for patients with heart failure, renal disease or mental health disorders. ${ }^{34}$ An Ontario study showed that patients with end-stage liver disease incurred an additional \$4201 in the last 90 days of life compared to other decedents. ${ }^{34}$ Extrapolating 30-day costs from our study shows that Status First Nations people with $\mathrm{HCV}$ infection incurred \$2679 more in their last 90 days of life than other Status First Nations people.
Differences in costs between people with HCV infection who lived within and outside of First Nations communities may indicate unique patterns of use of health care resources and health care policy by the 2 populations. ${ }^{35}$ A history of government mistrust, marginalization and alienation has created hesitancy among First Nations people to seek mainstream medical care, especially in rurally isolated communities with barriers to access to care. ${ }^{36}$ The largest difference in net costs was in the terminal phase, which may indicate that 
A

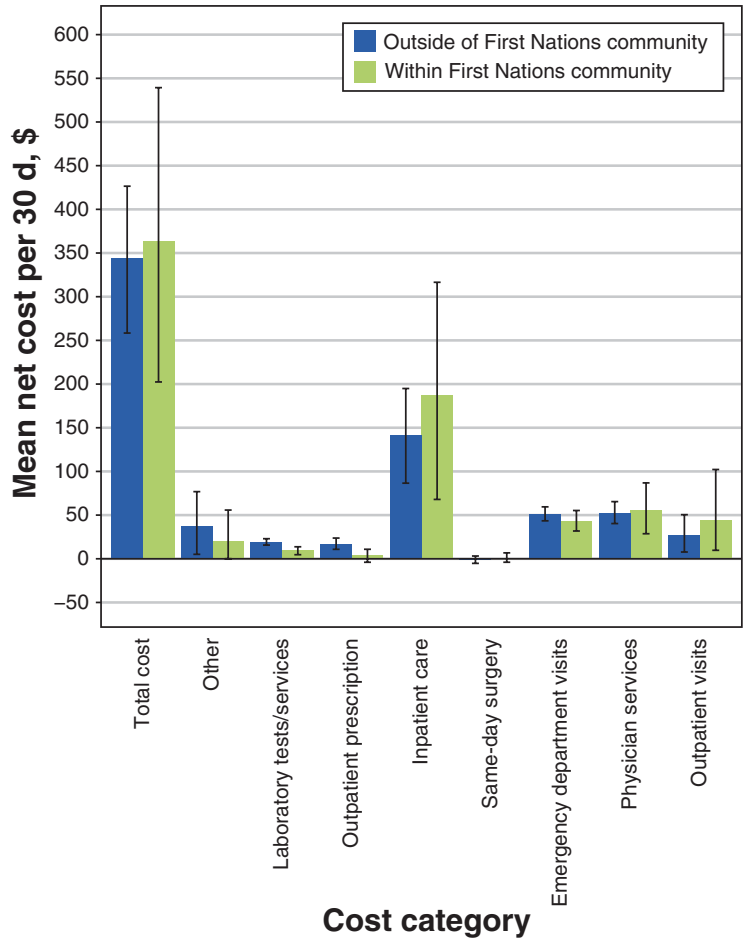

C

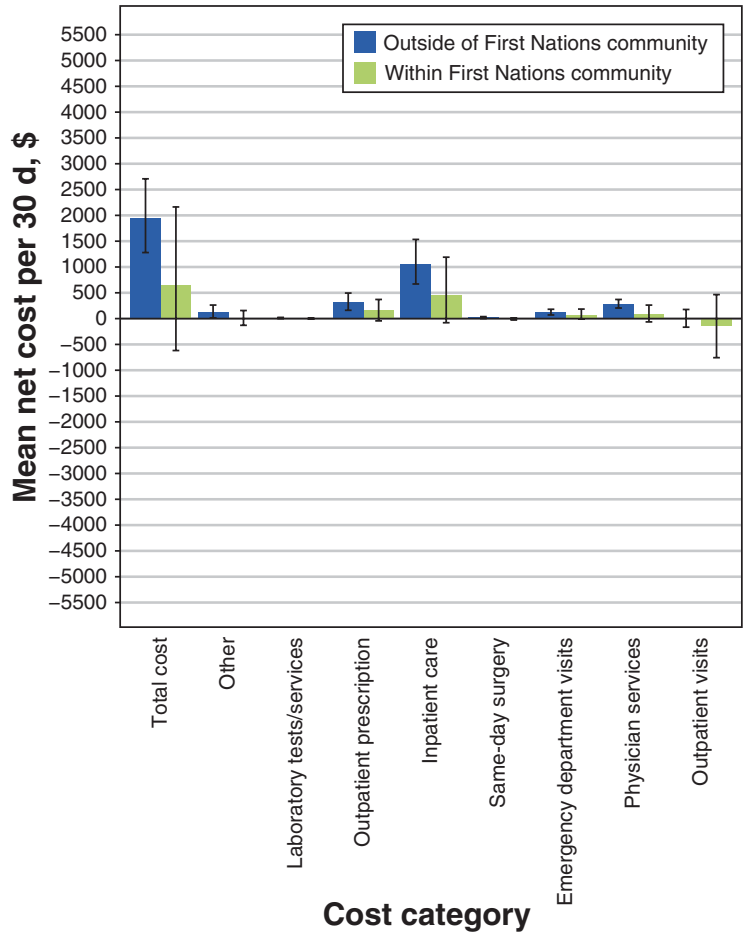

B

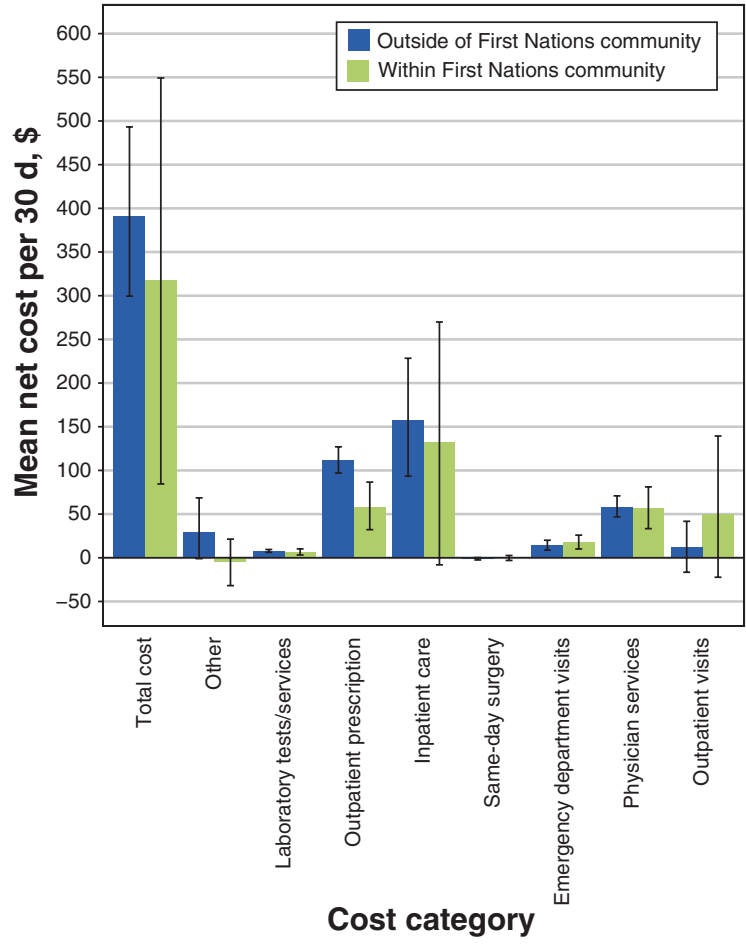

D

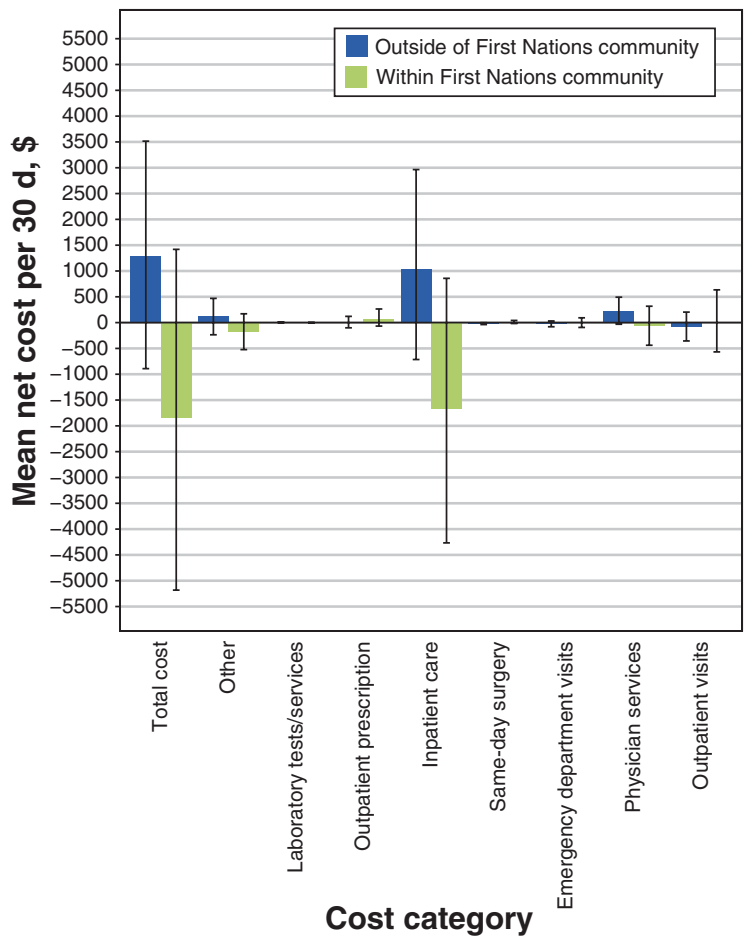

Figure 2: Net costs of care per 30 days by cost category for the prediagnosis (A), initial (B), late (C) and terminal (D) phases of care, stratified by residence within or outside of a First Nations community at matching date. Each cost is rounded to the nearest dollar and expressed in 2018 Canadian dollars. "Other" includes Ontario Health Insurance Plan nonphysician services, Assistive Devices Program, rehabilitation services, home care, complex continuing care and long-term care. Error bars represent $95 \%$ confidence intervals. Mean cost and net cost results stratified by community status can be found in Appendix 5, Supplemental Tables S8 and S9. 
A

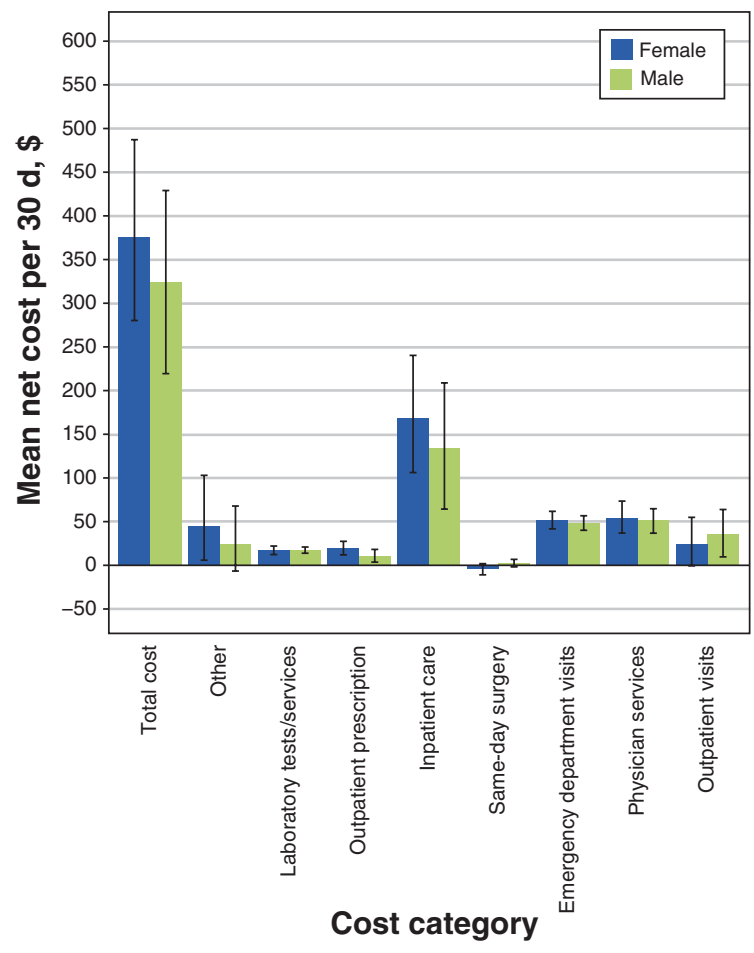

C

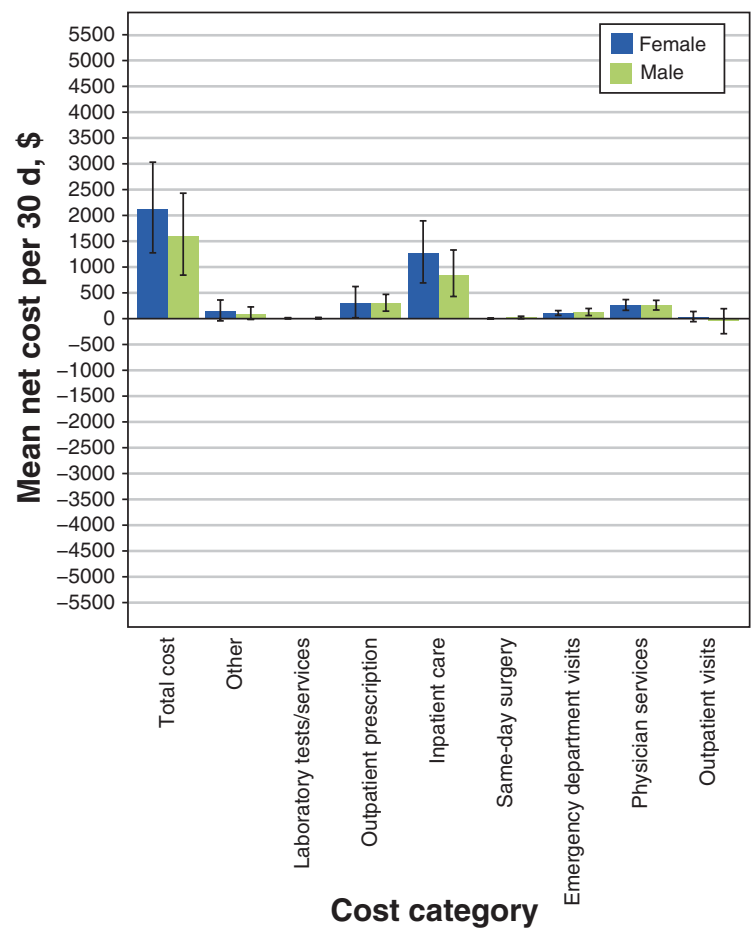

B

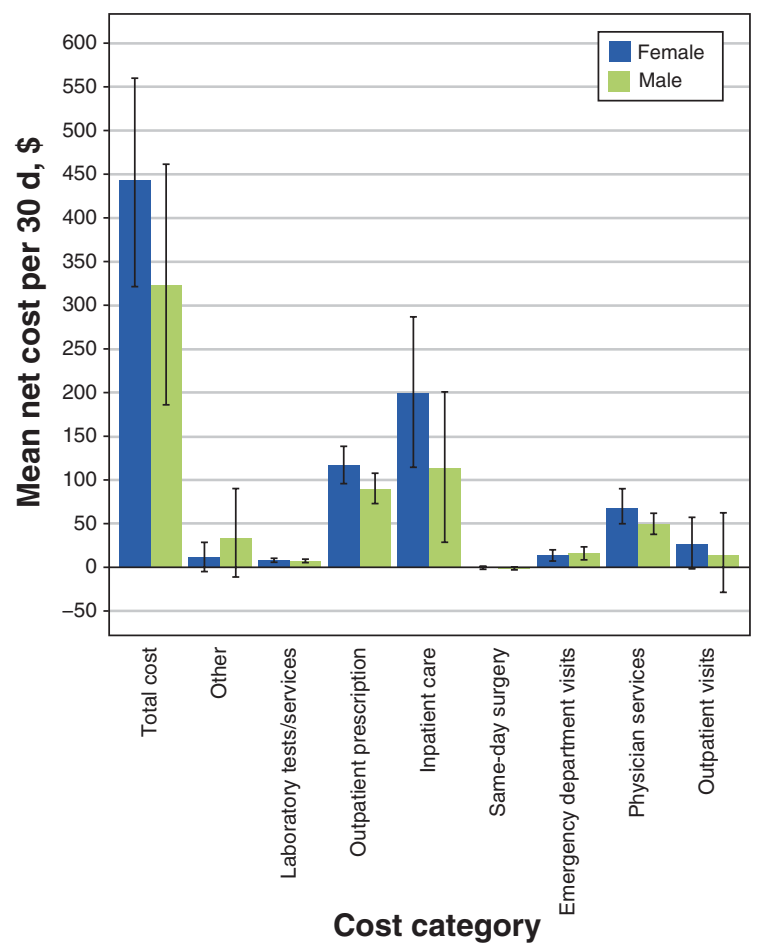

D

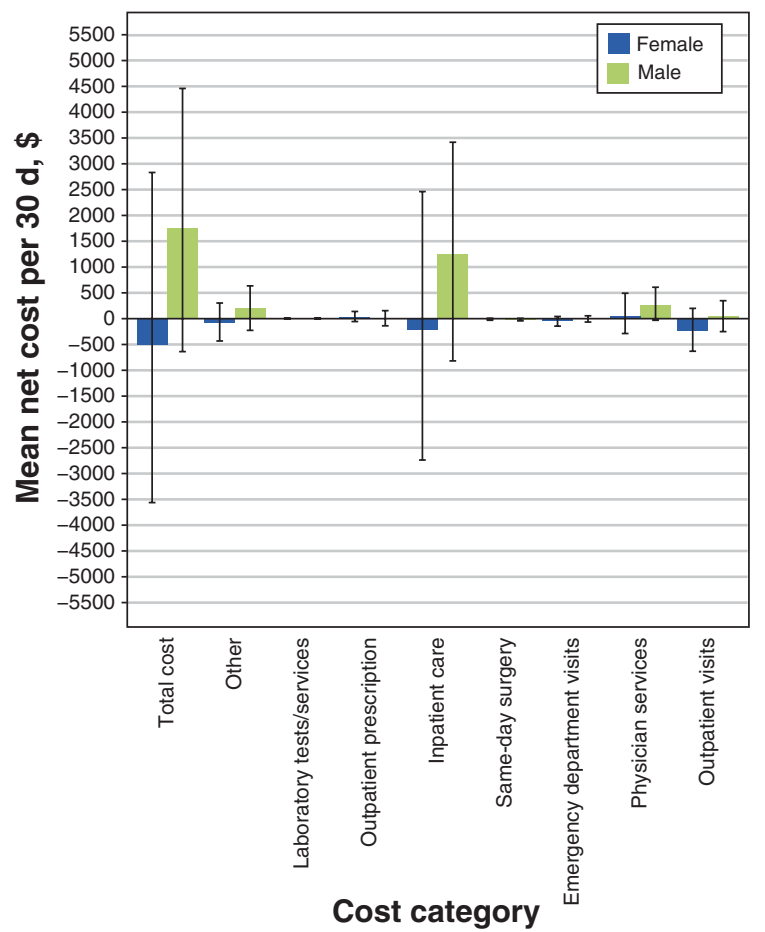

Figure 3: Net costs of care per 30 days by cost category for the prediagnosis (A), initial (B), late (C) and terminal (D) phases of care, stratified by sex. Each cost is rounded to the nearest dollar and expressed in 2018 Canadian dollars. "Other" includes Ontario Health Insurance Plan nonphysician services, Assistive Devices Program, rehabilitation services, home care, complex continuing care and long-term care. Error bars represent $95 \%$ confidence intervals. Mean cost and net cost results stratified by sex can be found in Appendix 5 , Supplemental Tables S10 and S11. 
end-of-life care within First Nations communities is associated with family support rather than hospital or hospice care. ${ }^{36}$ The lower cost of end-of-life care within First Nations communities may also be attributable to funding constraints, resulting in unavailable or limited access to end-of-life health care services. ${ }^{36}$ In addition, 1 in 4 First Nations communities in Ontario are in remote areas accessible only by air year round or by ice road in winter. ${ }^{37}$ These barriers can translate to people having to leave their community to seek care or, in certain cases, receiving no end-of-life care at all. ${ }^{36}$

In the prediagnosis, initial and late phases, female case participants exhibited higher costs of care than male case participants. Verde and $\mathrm{Li}^{38}$ found that First Nations women were more likely to have a family physician and seek health care services than First Nations men, perhaps owing to cultural norms regarding male strength and perception of less severe physical symptoms. Similarly, using ICES data, Green and colleagues $^{39}$ studied the monitoring, treatment and control of blood glucose and lipids in Status First Nations people with diabetes in Ontario and observed that women were more likely than men to be engaged in diabetes-related care. The higher net cost for males during the terminal phase in our study may indicate that males seek health care only when disease progresses to a critical stage. ${ }^{38}$ Also, females may choose traditional medicine and community supports rather than hospital or hospice care at the end of life (Evelynne Hill, Ontario First Nations HIV/AIDS Education Circle: personal communication, 2020).

Safe, effective and curative direct-acting antiviral treatments for HCV infection were introduced in Canada in 2012. ${ }^{40}$ However, Indigenous people face barriers in access to treatment. ${ }^{41}$ Although progression to advanced liver disease can take decades, ${ }^{42}$ the higher net costs in the late and terminal phases compared to the prediagnosis and initial phases forecast the potential economic impact if $\mathrm{HCV}$ infection remains untreated or is diagnosed late. Understanding health care expenditures in First Nations people with HCV infection can stimulate research, planning and evaluation of culturally specific services for combatting hepatitis $\mathrm{C}$ in this population. $^{43}$

\section{Limitations}

Although matching minimized differences between case and control participants, residual confounding and differences in health care-seeking behaviour potentially existed and may have introduced bias. The Public Health Ontario laboratory data set does not include all private diagnostic laboratory results. The Indian Register includes only First Nations people who are registered with the Canadian government. ${ }^{13}$ Our study included those who could be linked to ICES databases but excluded data for those who are members of communities in the Kenora Chiefs' Advisory.

Costs may be underestimated because ICES data sets do not capture federally funded or out-of-province health care services, including those covered by the Non-Insured Health Benefit program (drug coverage and certain health care services). The Ontario Drug Benefit program, our source of prescription information, covers only people aged 65 years or more, receiving social assistance or in long-term care homes.

We included all-cause mortality; thus, our terminal-phase net costs are not entirely attributable to $\mathrm{HCV}$ infection. ${ }^{4}$ Many mental health conditions could not be distinguished as being a cause or consequence of HCV infection. Because determination of residence in a given Local Health Integration Network and within a First Nations community relied on annual postal and residence codes updated at health card use or renewal, residence may have been misclassified.

As HCV infection can remain asymptomatic, control participants may have had undiagnosed infection. By excluding case participants with HIV and HBV infection, our study estimates reflect the cost of diagnosed monoinfection. Coinfection has been associated with potentially rapid fibrosis progression ${ }^{44}$ and different treatment of infection. Coinfection with HIV in particular has been associated with increased health care costs. ${ }^{4,45}$

\section{Conclusion}

Our results suggest that the costs of HCV infection in Status First Nations people vary by phase of care and increase as the disease progresses. Canada's commitment to partnership with First Nations people to eliminate hepatitis $\mathrm{C}$ will require measures that comprehensively depict its population-specific impact. Our population-specific health care costs can support research, planning and formulation of First Nations-specific prevention and treatment interventions for $\mathrm{HCV}$ infection.

\section{References}

1. Trubnikov M, Yan P, Archibald C. Estimated prevalence of hepatitis C virus infection in Canada, 2011. Can Commun Dis Rep 2014;40:429-36.

2. Li H, Huang MH, Jiang JD, et al. Hepatitis C: from inflammatory pathogenesis to anti-inflammatory/hepatoprotective therapy. World 7 Gastroenterol 2018; 24:5297-311.

3. Kwong JC, Crowcroft NS, Campitelli MA, et al.; Ontario Burden of Infectious Disease Study Advisory Group. Ontario Burden of Infectious Disease Study (ONBOIDS): an OAHPP/ICES report. Toronto: Ontario Agency for Health Protection and Promotion, Institute for Clinical Evaluative Sciences; 2010.

4. Krajden M, Kuo M, Zagorski B, et al. Health care costs associated with hepatitis C: a longitudinal cohort study. Can 7 Gastroenterol 2010;24:717-26.

5. Kelly EM, James PD, Murthy S, et al. Health care utilization and costs for patients with end-stage liver disease are significantly higher at the end of life compared to those of other decedents. Clin Gastroenterol Hepatol 2019;17:233946.e1.

6. Myers RP, Krajden M, Bilodeau M, et al. Burden of disease and cost of chronic hepatitis C virus infection in Canada. Can 7 Gastroenterol Hepatol 2014;28: 243-50.

7. Greenwood M, Leeuw SD, Lindsay NM, et al., editors. Determinants of Indigenous Peoples' bealth in Canada: beyond the social. Toronto: Canadian Scholars; 2015.

8. Uhanova J, Tate RB, Tataryn DJ, et al. The epidemiology of hepatitis C in a Canadian Indigenous population. Can 7 Gastroenterol 2013;27:336-40.

9. Global hepatitis report 2017. Geneva: World Health Organization; 2017. Available: http://apps.who.int/iris/bitstream/10665/255016/1/9789241565455-eng. pdf?ua=1 (accessed 2018 Apr. 25).

10. Jacklin K, Walker J. Cultural understandings of dementia in Indigenous peoples: a qualitative evidence synthesis. Can 7 Aging 2020;39:220-34.

11. Walker J, Lovett R, Kukutai T, et al. Indigenous health data and the path to healing. Lancet 2017;390:2022-3.

12. Pyper E, Henry D, Yates EA, et al. Walking the path together: Indigenous health data at ICES. Healthc Q 2018;20:6-9.

13. Slater M, Green ME, Shah B, et al. First Nations people with diabetes in Ontario: methods for a longitudinal population-based cohort study. CMAf Open 2019;7:E680-8.

14. Mendlowitz A. The health burden of hepatitis $\mathrm{C}$ infection facing the First Nations population in Ontario: a research partnership [oral presentation]. Canadian Liver Meeting; 2020 Feb. 28; Montréal.

15. Indian Act (R.S.C., 1985, c. I-5). Available: https://laws-lois.justice.gc.ca/eng/ acts/I-5/ (accessed 2020 Sept. 11). 
16. The Johns Hopkins ACG® system. Baltimore: Johns Hopkins University. Available: www.hopkinsacg.org/ (accessed 2019 Feb. 7).

17. du Plessis V, Beshiri R, Bollman RD, et al. Definitions of rural. Rural and Small Town Canada Analysis Bulletin 2001;3(3):1-16. Cat no 21-006-XIE. Available: www150.statcan.gc.ca/n1/pub/21-006-x/21-006-x2001003-eng.pdf (accessed 2020 July 28).

18. Austin PC. Assessing balance in measured baseline covariates when using many-to-one matching on the propensity-score. Pharmacoepidemiol Drug Saf 2008; 17:1218-25.

19. Lapointe-Shaw L, Georgie F, Carlone D, et al. Identifying cirrhosis, decompensated cirrhosis and hepatocellular carcinoma in health administrative data: a validation study. PLoS One 2018;13:e0201120.

20. Rosenberg SD, Goodman LA, Osher FC, et al. Prevalence of HIV, hepatitis B, and hepatitis C in people with severe mental illness. Am 7 Public Health 2001; 91:31-7.

21. Adinolfi LE, Nevola R, Rinaldi L, et al. Chronic hepatitis $C$ virus infection and depression. Clin Liver Dis 2017;21:517-34.

22. Golden J, O'Dwyer AM, Conroy RM. Depression and anxiety in patients with hepatitis C: prevalence, detection rates and risk factors. Gen Hosp Psychiatry 2005;27:431-8.

23. Lehman CL, Cheung RC. Depression, anxiety, post-traumatic stress, and alcohol-related problems among veterans with chronic hepatitis C. Am 7 Gastroenterol 2002;97:2640-6.

24. MHASEF Research Team. Mental bealth and addictions system performance in Ontario: a baseline scorecard. Toronto: ICES; 2018. Available: https://www.ices. on.ca/Publications/Atlases-and-Reports/2018/MHASEF (accessed 2019 Dec. 17).

25. Ostapowicz G, Watson KJ, Locarnini SA, et al. Role of alcohol in the progression of liver disease caused by hepatitis C virus infection. Hepatology 1998;27: 1730-5.

26. Thein HH, Isaranuwatchai $W$, Campitelli MA, et al. Health care costs associated with hepatocellular carcinoma: a population-based study. Hepatology 2013; 58:1375-84.

27. de Oliveira C, Pataky R, Bremner KE, et al. Phase-specific and lifetime costs of cancer care in Ontario, Canada. BMC Cancer 2016;16:809.

28. Krahn MD, Zagorski B, Laporte A, et al. Healthcare costs associated with prostate cancer: estimates from a population-based study. BfU Int 2010;105: 338-46.

29. Wodchis WP, Bushmeneva K, Nikitovic M, et al. Guidelines on person-level costing using administrative databases in Ontario. Working Paper Series vol 1. Toronto: Health System Performance Research Network; 2013. Available: https://tspace.library.utoronto.ca/handle/1807/87373 (accessed 2020 July 14).

30. Consumer price index portal. Ottawa: Statistics Canada; modified 2021 Mar. 17. Available: www.statcan.gc.ca/eng/subjects-start/prices_and_price_ indexes/consumer_price_indexes (accessed 2020 July 28).

31. Glick HA, Doshi JA, Sonnad SS, et al. Economic evaluation in clinical trials. 2nd ed. Oxford (UK): Oxford University Press; 2014.

32. National health expenditure trends, 1975 to 2019. Ottawa: Canadian Institute for Health Information; 2019.

33. Federico CA, Hsu PC, Krajden M, et al. Patient time costs and out-of-pocket costs in hepatitis C. Liver Int 2012;32:815-25.

34. Kelly EM, James PD, Murthy S, et al. Health care utilization and costs for patients with end-stage liver disease are significantly higher at the end of life compared to those of other decedents. Clin Gastroenterol Hepatol 2019;17:233946.e1.

35. Horrill T, McMillan DE, Schultz ASH, et al. Understanding access to healthcare among Indigenous peoples: a comparative analysis of biomedical and postcolonial perspectives. Nurs Inq 2018;25:e12237.

36. Russell B, Fred DE, Brown C. Culturally safe end-of-life care for First Nations persons living on reserve. Rural Remote Health 2018;18:4500.

37. In the spirit of reconciliation: the Ministry of Indigenous Relations and Reconciliation's first 10 years. Toronto: Government of Ontario. Available: https:// files.ontario.ca/books/in_spirit_of_reconciliation_pdf_0.pdf (accessed 2021 Apr. 15).

38. Verde M, Li HZ. Are Native men and women accessing the health care facilities? Findings from a small Native reserve. Can 7 Native Stud 2003;23:113-33.

39. Green ME, Shah BR, Slater M, et al. Monitoring, treatment and control of blood glucose and lipids in Ontario First Nations people with diabetes. CMA7 2020;192:E937-45

40. Schanzer D, Pogany L, Aho J, et al. Impact of availability of direct-acting antivirals for hepatitis C on Canadian hospitalization rates, 2012-2016. Can Commun Dis Rep 2018;44:150-6.

41. Nitulescu R, Young J, Saeed S, et al.; Canadian Co-Infection Cohort Study. Variation in hepatitis $\mathrm{C}$ virus treatment uptake between Canadian centres in the era of direct-acting antivirals. Int 7 Drug Policy 2019;65:41-9.

42. Chen SL, Morgan TR. The natural history of hepatitis C virus (HCV) infection. Int 7 Med Sci 2006;3:47-52.

43. Canadian Network on Hepatitis C Blueprint Writing Committee and Working Groups. Blueprint to inform hepatitis C elimination efforts in Canada. Montréal:
Canadian Network on Hepatitis C; 2019. Available: www.canhepc.ca/sites/ default/files/media/documents/blueprint_hcv_2019_05.pdf (accessed 2020 July 17).

44. Erman A, Krahn MD, Hansen T, et al. Estimation of fibrosis progression rates for chronic hepatitis $\mathrm{C}$ : a systematic review and meta-analysis update. $B M 7$ Open 2019;9:e027491.

45. Mattingly TJ 2nd, Pandit NS, Onukwugha E. Burden of co-infection: a cost analysis of human immunodeficiency virus in a commercially insured hepatitis C virus population. Infect Dis Ther 2019;8:219-28.

Affiliations: Institute of Health Policy, Management and Evaluation (Mendlowitz, Sander, Isaranuwatchai, Krahn), University of Toronto; Toronto Health Economics and Technology Assessment (THETA) Collaborative (Mendlowitz, Bremner, Sander, Krahn), University Health Network; ICES Central (Mendlowitz, Walker, Sander, Krahn), Toronto, Ont.; School of Rural and Northern Health (Walker), Laurentian University, Sudbury, Ont.; School of Pharmacy (Wong), University of Waterloo, Waterloo, Ont.; Toronto Centre for Liver Disease (Feld), Toronto General Hospital; Public Health Ontario (Sander), Toronto, Ont.; Ontario First Nations HIV/AIDS Education Circle (Jones), London, Ont.; St. Michael's Hospital (Isaranuwatchai), Unity Health Toronto, Toronto, Ont.

Contributors: Andrew Mendlowitz and Lyndia Jones conceived the study. Andrew Mendlowitz analyzed the data. Andrew Mendlowitz, Karen Bremner and Murray Krahn drafted the manuscript. All of the authors were involved in designing the study, interpreting the data and revising the manuscript, approved the final version to be published and agreed to be accountable for all aspects of the work.

Funding: This study was supported by ICES, which is funded by an annual grant from the Ontario Ministry of Health. This study was also funded by Canadian Institutes of Health Research (CIHR) Project Grant 166039 and by a doctoral trainee fellowship to Andrew Mendlowitz from the Canadian Network on Hepatitis C (CanHepC). CanHepC is funded by a joint initiative of the CIHR (NHC-142832) and the Public Health Agency of Canada. This work was also supported by funding from the Canada Research Chairs Program to Murray Krahn, Jennifer Walker and Beate Sander, and an Ontario Early Researcher Award to William Wong.

Content licence: This is an Open Access article distributed in accordance with the terms of the Creative Commons Attribution (CC BY-NCND 4.0) licence, which permits use, distribution and reproduction in any medium, provided that the original publication is properly cited, the use is noncommercial (i.e., research or educational use), and no modifications or adaptations are made. See: https://creativecommons.org/licenses/by-nc -nd $/ 4.0 \%$.

Data sharing: The data set from this study is held securely in coded form at ICES. Although data-sharing agreements prohibit ICES from making the data set publicly available, access may be granted to those who meet prespecified criteria for confidential access, available at https://www.ices. on.ca/DAS. The full data set creation plan and underlying analytic code are available from the authors on request, with the understanding that the computer programs may rely on coding templates or macros that are unique to ICES and are therefore either inaccessible or may require modification.

Acknowledgements: The authors thank the Ontario First Nations HIV/ AIDS Education Circle (OFNHAEC) and its members for their partnership and insightful comments and thoughtful input throughout this study. The authors also acknowledge OFNHAEC for their permission and guidance in the final dissemination of this project. They also thank Christina Diong and Ruth Croxford for guidance on the analyses.

Disclaimer: The opinions, results and conclusions reported in this article are those of the authors and are independent from the funding sources. No endorsement by ICES or the Ontario Ministry of Health is intended or should be inferred.

Supplemental information: For reviewer comments and the original submission of this manuscript, please see www.cmajopen.ca/content/9/3/ E897/suppl/DC1. 